\title{
Near-Infrared Light-Induced Self-Powered Aptasensing Platform for Aflatoxin B1 Based on Upconversion Nanoparticles-Doped $\mathrm{Bi}_{2} \mathrm{~S}_{3}$ Nanorods
}

Jie Gao, Xiaoling Yao, Yingxu Chen, Zhonghong Gao, Jingdong Zhang*

Key Laboratory of Material Chemistry for Energy Conversion and Storage (Ministry of Education), School of Chemistry and Chemical Engineering, Huazhong University of Science and Technology, Wuhan 430074, P. R. China.

\section{Table of Contents}

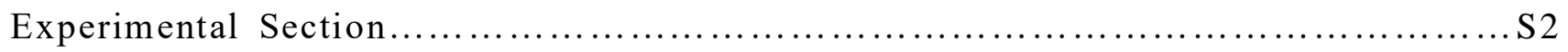

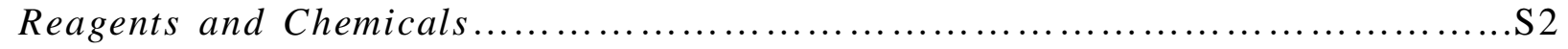

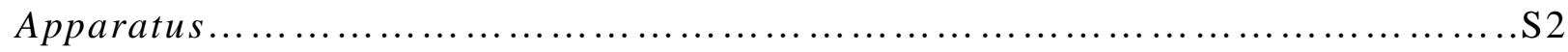

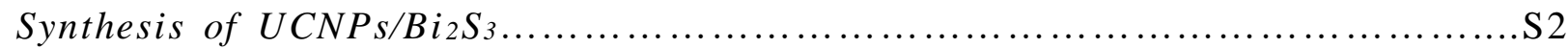

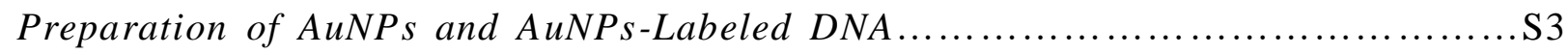

Modification of Electrode and Self-Powered Sensing Process.......................... 3

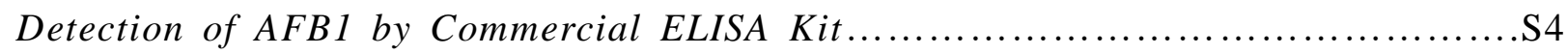

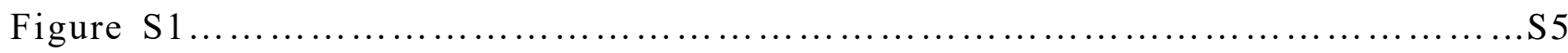

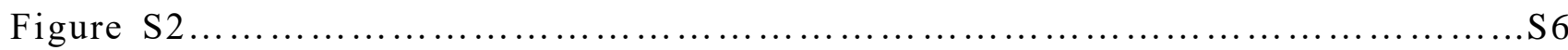

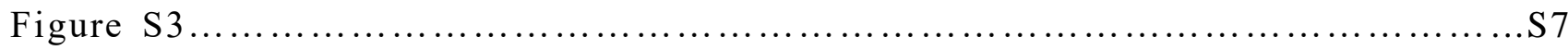

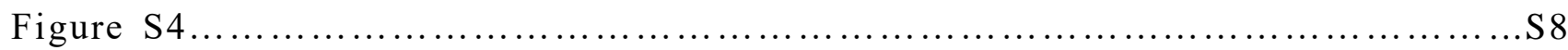

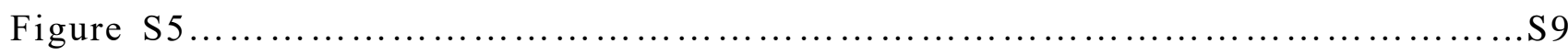

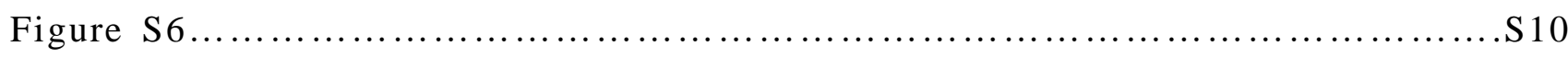

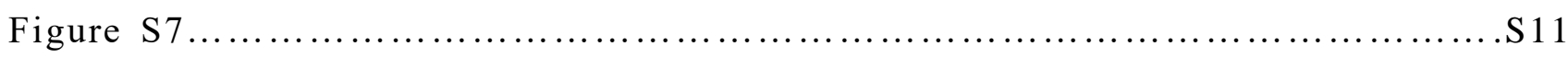

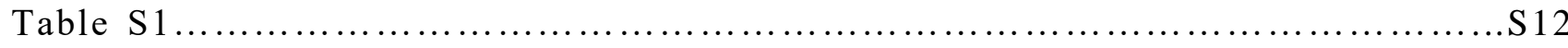

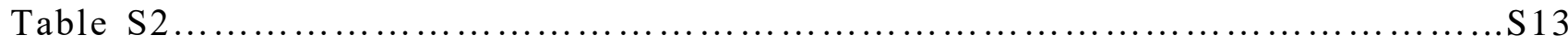

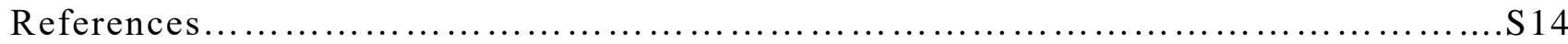




\section{Experimental Section}

\section{Reagents and Chemicals}

$\mathrm{YCl}_{3} \cdot 6 \mathrm{H}_{2} \mathrm{O}(99.9 \%), \mathrm{YbCl}_{3} \cdot 6 \mathrm{H}_{2} \mathrm{O}(99.9 \%), \mathrm{ErCl}_{3} \cdot 6 \mathrm{H}_{2} \mathrm{O}(99.9 \%)$, polyethyleneimine (PEI, MW $600,99 \%$ ), $\mathrm{Na}_{2} \mathrm{~S} \cdot 9 \mathrm{H}_{2} \mathrm{O}, \mathrm{HAuCl}_{4} \cdot 3 \mathrm{H}_{2} \mathrm{O}, \mathrm{N}$-hydroxysuccinimide (NHS), N-(3-dimethylaminopropyl)N'-ethylcarbodiimide hydrochloride (EDC), and tris (2-carboxyethyl)-phosphine hydrochloride (TCEP) were provided by Aladdin Reagent Co. Ltd. (Shanghai, China). NaCl, $\mathrm{NH}_{4} \mathrm{~F}$, $\mathrm{Bi}\left(\mathrm{NO}_{3}\right)_{3} \cdot 5 \mathrm{H}_{2} \mathrm{O}$, carbamide, sodium citrate and ethylene glycol were obtained from Sinopharm Chemical Reagent Co. Ltd. (Shanghai, China). Aflatoxin B1 enzyme-linked immunosorbent assay (ELISA) kit was obtained from Beosen (Jiangsu) Food Safety Technology Co., Ltd. (Wuxi, China). AFB1, the aminated AFB1 aptamer, nonfunctional DNA sequence and thiolated complementary DNA sequence (HS-cDNA) were purchased from Shanghai Sangon Biotechnology Co., Ltd. (Shanghai, China). The sequence of nucleotides in the aptamers is shown below.

AFB1 aptamer sequence:

5'-NH $2-\left(\mathrm{CH}_{2}\right)_{6}-\mathrm{GTT}$ GGG CAC GTG TTG TCT CTC TGT GTC TCG TGC CCT TCG CTA GGC CCA CA-3',

Nonfunctional DNA sequence (the substituted bases are marked in red):

5'-NH2-(CH2)6-GAT GGG CAC GTC TTG TCT CTC AGT GTC TCG TAC CCT TCG CTA GGC CCA CA-3'

HS-cDNA sequence:

5'-SH-(CH2)6-TTT TTG TGG GCC TAG-3'.

\section{Apparatus}

Scanning electron microscopy (SEM, Nova Nano SEM 450, Netherlands) equipped with an energy dispersive spectra (EDS, IE250X-Max50, UK) detector was used to observe the morphology and composition of samples. The powder X-ray diffraction (XRD) analysis was carried out on a D8 Advance X-Ray diffractometer (SESmartLab, Rigaku instrument, Japan) operating at $40 \mathrm{kV}$ accelerating voltage and applied current of $40 \mathrm{~mA}$ with $\mathrm{Cu} \mathrm{K} \alpha$ radiation. The fluorescence measurement was performed on a FLS1000 fluorescence spectrophotometer (Edinburgh instruments Ltd., UK).The UV-vis-IR diffuse reflectance spectra (DRS) were analyzed by using a UV-3600 spectrophotometer (SHIMADZU, Japan). The absorption spectrum of ELISA reaction solution was measured by a UV-vis absorption spectrophotometer (UV-2700, SHIMADZU, Japan). All electrochemical and photoelectrochemical (PEC) measurements were carried out on a CHI660A electrochemical workstation (Shanghai Chenhua Instrument Co. Ltd., China) with a 500-mW NIR light irradiation at $980 \mathrm{~nm}$.

\section{Synthesis of $U C N \mathrm{Ps}_{\mathrm{s}} / \mathrm{Bi}_{2} \mathrm{~S}_{3}$}

The upconversion nanoparticles of $\mathrm{NaYF}_{4}: \mathrm{Yb}, \mathrm{Er}$ (denoted as UCNPs) were synthesized accord- 
ing to a previous report with some modification. ${ }^{1}$ Briefly, $2 \mathrm{mmol}$ of $\mathrm{LnCl}_{3}\left(78 \% \mathrm{Y}^{3+}, 20 \% \mathrm{Yb}^{3+}, 2 \%\right.$ $\left.\mathrm{Er}^{3+}\right)$ and $\mathrm{NaCl}(4 \mathrm{mmol})$ were dissolved into ethylene glycol (EG) solution (30 mL). The obtained solution was noted as solution A. Meanwhile, $8 \mathrm{mmol} \mathrm{NH}_{4} \mathrm{~F}$ and polyethyleneimine $(0.8 \mathrm{~g})$ were dissolved into EG solution (20 mL) as solution B. Then, solution B was added dropwise to solution A and vigorously stirred for $20 \mathrm{~min}$. Following that, the mixture was transferred into a $100 \mathrm{~mL}$ Teflonlined autoclave and heated at $200{ }^{\circ} \mathrm{C}$ for $2 \mathrm{~h}$. The product was separated via centrifugation and further cleaned with water and ethanol. Finally, it was dried in an oven at $60{ }^{\circ} \mathrm{C}$ overnight.

$\mathrm{Bi}_{2} \mathrm{~S}_{3}$ was synthesized according to a solvothermal method. ${ }^{2}$ Briefly, $1.82 \mathrm{~g} \mathrm{Bi}\left(\mathrm{NO}_{3}\right)_{3} \cdot 5 \mathrm{H}_{2} \mathrm{O}$, $1.35 \mathrm{~g} \mathrm{Na} 2 \mathrm{~S} \cdot 9 \mathrm{H}_{2} \mathrm{O}$ and $1.92 \mathrm{~g}$ carbamide were added to $75 \mathrm{~mL} \mathrm{EG}$ solution and vigorously stirred for $20 \mathrm{~min}$. The resultant mixture was then transferred into a Teflon-lined autoclave and heated at $180{ }^{\circ} \mathrm{C}$ for $24 \mathrm{~h}$. The obtained product was repeatedly washed with deionized water and ethanol and dried at $60{ }^{\circ} \mathrm{C}$ overnight.

The UCNPs/ $\mathrm{Bi}_{2} \mathrm{~S}_{3}$ composite was prepared by directly mixing UCNPs and $\mathrm{Bi}_{2} \mathrm{~S}_{3}$ suspensions. A uniform suspension was then obtained by ultrasonic agitation of the mixture for $30 \mathrm{~min}$. To obtain different concentrations of $\mathrm{UCNPs} / \mathrm{Bi}_{2} \mathrm{~S}_{3}$ composites, the two suspensions were mixed in varying weight ratios and expressed as $\mathrm{x} \% \mathrm{UCNPs} / \mathrm{Bi}_{2} \mathrm{~S}_{3}$. Generally, $15 \% \mathrm{UCNPs} / \mathrm{Bi}_{2} \mathrm{~S}_{3}$ was used except where otherwise indicated.

\section{Preparation of AuNPs and AuNPs-Labeled DNA}

The $\mathrm{Au}$ nanoparticles (AuNPs) were prepared according to the literature. ${ }^{3}$ At first, $50 \mathrm{~mL}$ of $0.01 \%(\mathrm{w} / \mathrm{w}) \mathrm{HAuCl}_{4}$ was heated to boiling. Then, $2 \mathrm{~mL}$ of $1 \%$ sodium citrate solution was added into the above boiling solution and heated for another $20 \mathrm{~min}$. Finally, the product was cooled down to room temperature and stored away from light.

The AuNPs-labeled DNA was prepared by the following steps. Initially, a mixed solution of 10 $\mu \mathrm{L}$ TCEP $(10 \mathrm{mM})$ and $100 \mu \mathrm{L}$ SH-cDNA $(10 \mu \mathrm{M})$ was shaken for $0.5 \mathrm{~h}$ at $4{ }^{\circ} \mathrm{C}$ to reduce disulfide bonds. Subsequently, a certain amount of AuNPs and TE buffer ( $\mathrm{pH}$ 8) were added to make up the final volume of the reaction solution to $1 \mathrm{~mL}$. The mixture was incubated with thermostat oscillator at $4{ }^{\circ} \mathrm{C}$ overnight under dark condition. Finally, the mixture was centrifuged for $15 \mathrm{~min}$ at $13000 \mathrm{rpm}$ to remove excess HS-cDNA and the precipitate was stored in TE buffer.

\section{Modification of Electrode and Self-Powered Sensing Process}

The photoanode was fabricated by modifying ITO with UCNPs $/ \mathrm{Bi}_{2} \mathrm{~S}_{3}$. The pretreatment of the ITO electrode was the same as that described in our previous work. ${ }^{4}$ Then, $10 \mu \mathrm{L} \mathrm{UCNPs} / \mathrm{Bi}_{2} \mathrm{~S}_{3}$ suspension $\left(3 \mathrm{~g} \cdot \mathrm{L}^{-1}\right)$ was modified on an ITO electrode with a surface area of $0.0706 \mathrm{~cm}^{2}$ and dried at $60{ }^{\circ} \mathrm{C}$. Afterward, the electrode was incubated with a mixture of EDC $\left(10 \mathrm{mg} \cdot \mathrm{mL}^{-1}\right)$ and NHS $(10$ $\mathrm{mg} \cdot \mathrm{mL}^{-1}$ ) for $30 \mathrm{~min}$. After rinsing the electrode surface with water, $8 \mu \mathrm{L}$ of AFB 1 aptamer at a desired concentration was coated onto the activated electrode surface at $37^{\circ} \mathrm{C}$ for $2 \mathrm{~h}$. After rinsing, 10 $\mu \mathrm{L}$ of $0.5 \%$ BSA solution was coated on electrode surface for $30 \mathrm{~min}$ to completely block the un- 
bound sites and the electrode was washed with water to remove excess reactants. The AFB1 standard solution (or real sample solution) was incubated with modified electrodes at $37{ }^{\circ} \mathrm{C}$ for $1 \mathrm{~h}$ and washed with water. Then, AuNPs-cDNA was hybridized with the unreacted aptamer at the $37{ }^{\circ} \mathrm{C}$ for $2 \mathrm{~h}$. Finally, the modified electrode was washed with water. The PFC was fabricated with the aforementioned photoanode and Pt cathode in a quartz cell containing $0.1 \mathrm{M} \mathrm{Na}_{2} \mathrm{SO}_{4}$. The $V-I$ curve of the PFC was obtained by galvanos-tatic polarization technique. The output power density $(P-I)$ curve was acquired by plotting the power density $(V \times I / A)$ vs. the current $(I)$, where $A$ was the geometric area of the photoanode.

Detection of AFB1 by Commercial ELISA Kit

The detection of AFB1 by commercial ELISA kit followed the instruction by performing colorimetric immunoassay in a 48 -well plate. First, $50 \mu \mathrm{L}$ AFB1 standard solution (or real sample solution) and $50 \mu \mathrm{L}$ enzyme-labeled antigen were added in each well. After incubating for 20 min at $37^{\circ} \mathrm{C}$, the well was washed with washing solution three times. Then, substrate solution $(50 \mu \mathrm{L})$ and chromogen $(50 \mu \mathrm{L})$ were added and incubated for $15 \mathrm{~min}$ at $37^{\circ} \mathrm{C}$. Finally, stop reagent $(50 \mu \mathrm{L})$ was added to end reaction. The absorbance of the reaction solution was measured at $450 \mathrm{~nm}$. 


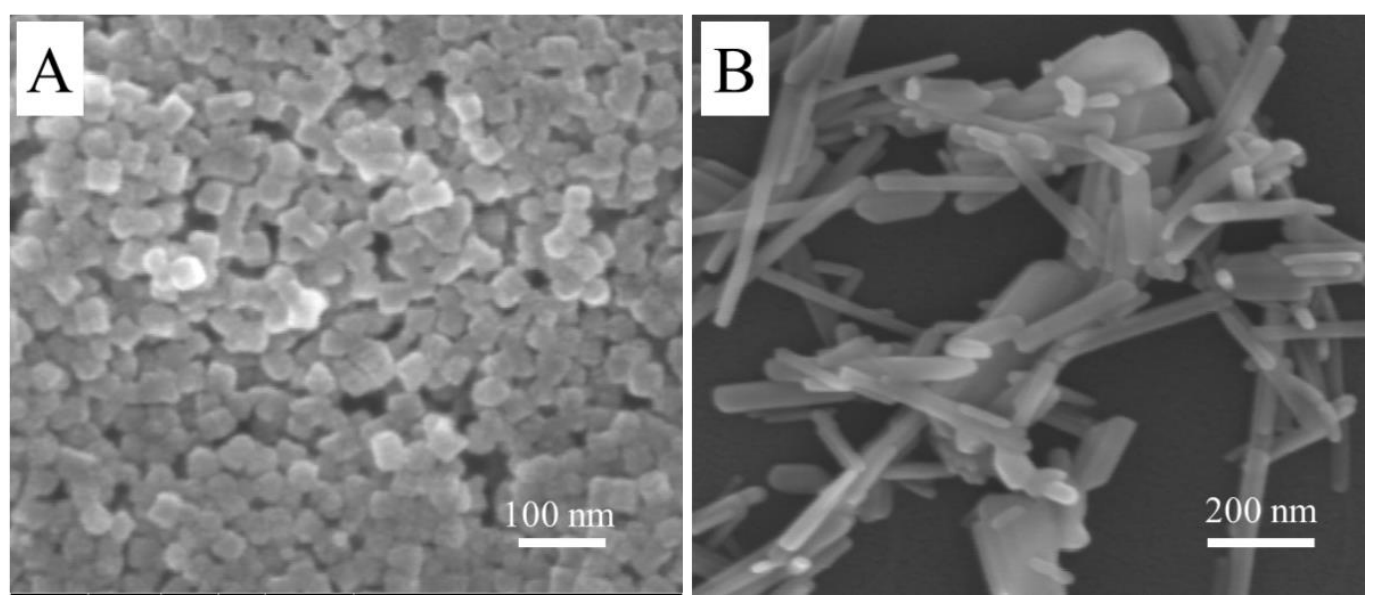

Figure S1. SEM images of (A) UCNPs and (B) $\mathrm{Bi}_{2} \mathrm{~S}_{3}$. 


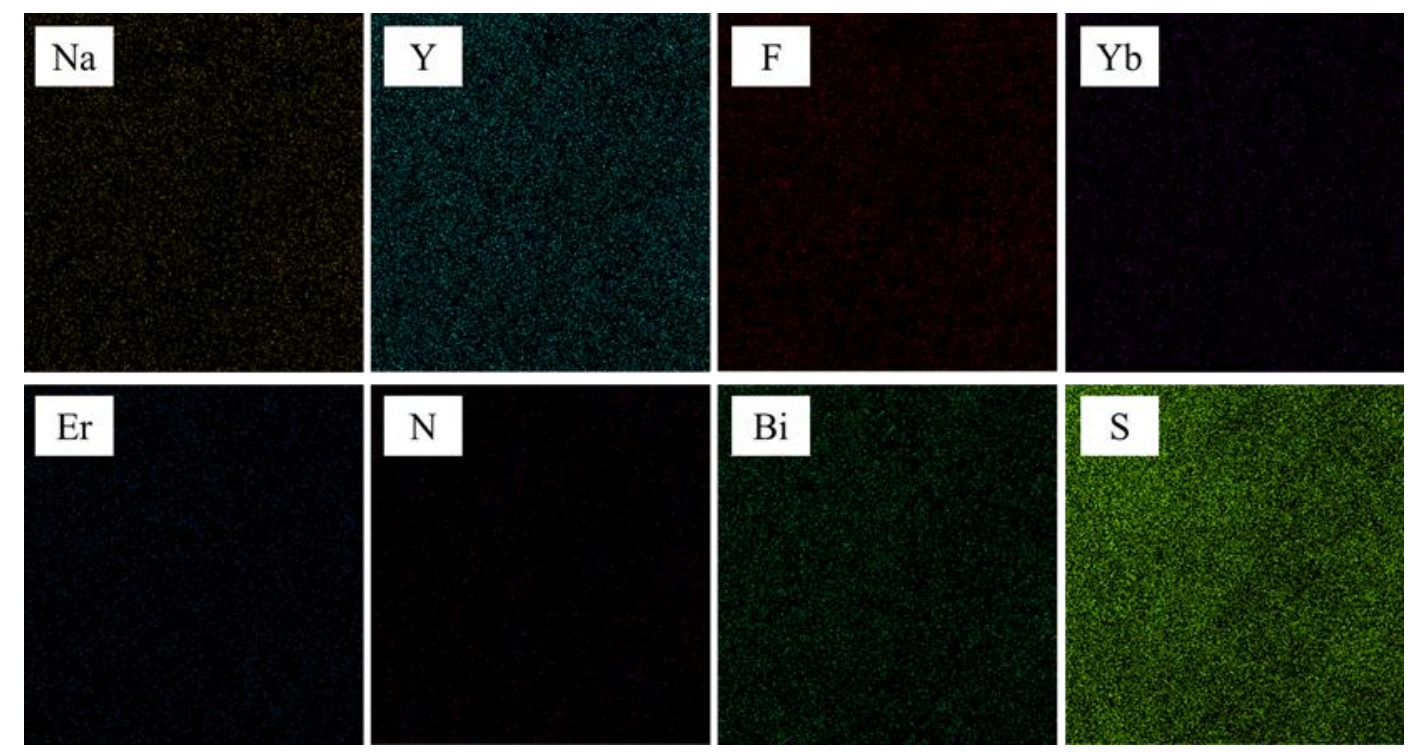

Figure S2. Elemental mapping of UCNPs/ $\mathrm{Bi}_{2} \mathrm{~S}_{3}$. 

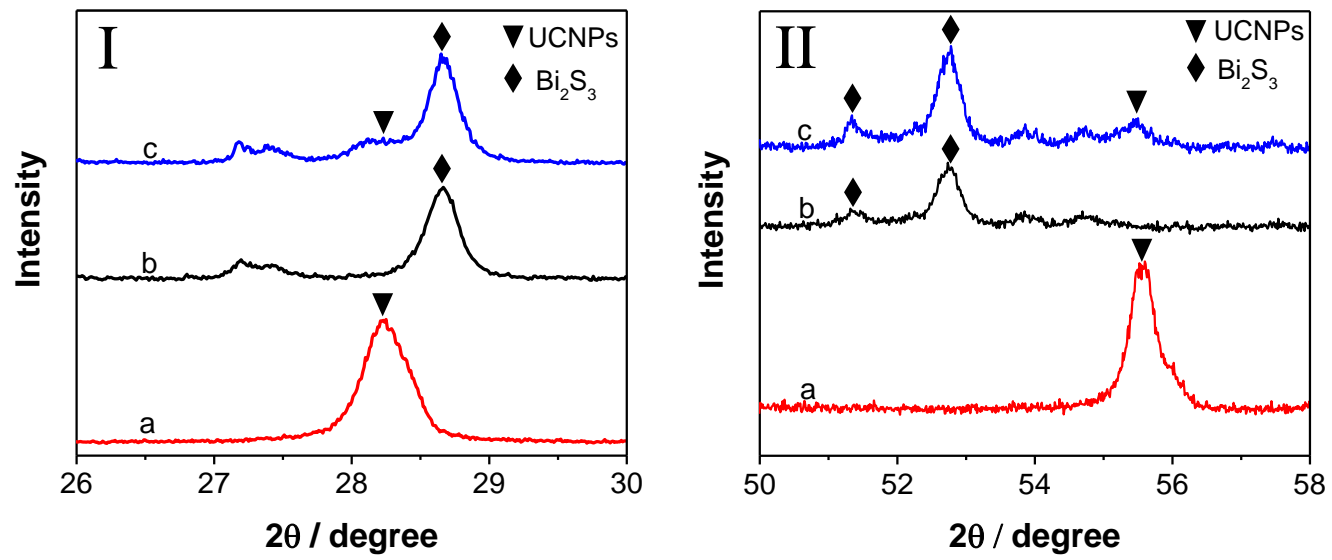

Figure S3. Enlarged regions marked in the XRD patterns in Figure 1B for (a) UCNPs, (b) $\mathrm{Bi}_{2} \mathrm{~S}_{3}$ and (c) $\mathrm{UCNP} / \mathrm{Bi}_{2} \mathrm{~S}_{3}$. 

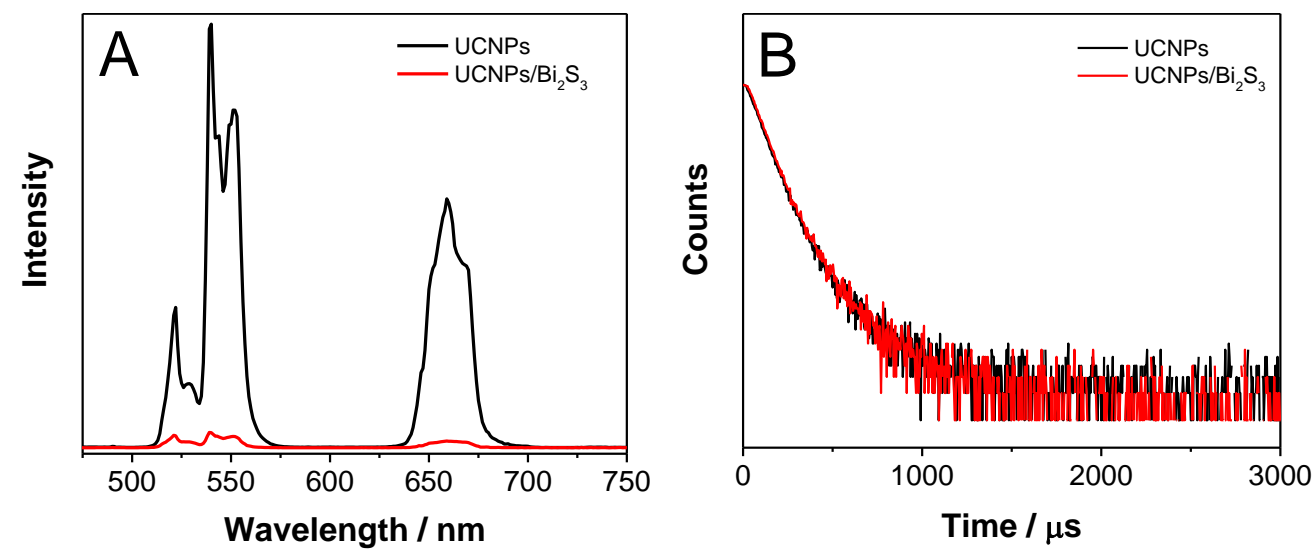

Figure S4. (A) Upconversion luminescence spectra of UCNPs and UCNPs/Bi2 $\mathrm{S}_{3}$. (B) Decay curves of UCNPs and UCNPs/Bi2 $\mathrm{S}_{3}$ at an emission wavelength of $540 \mathrm{~nm}$. 


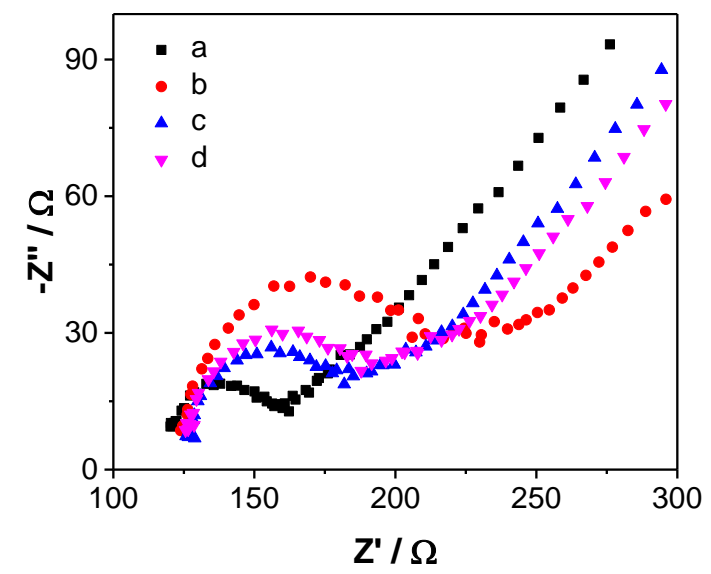

Figure S5. Nyquist plots of different modified ITO electrodes in $0.1 \mathrm{M} \mathrm{KCl}$ containing $5.0 \mathrm{mM}$ $\mathrm{K}_{3} \mathrm{Fe}(\mathrm{CN})_{6} / \mathrm{K}_{4} \mathrm{Fe}(\mathrm{CN})_{6} \quad$ (1:1): (a) $\mathrm{UCNPs} / \mathrm{Bi}_{2} \mathrm{~S}_{3} / \mathrm{ITO}$ ， (b) aptamer/UCNPs/Bi $\mathrm{S}_{3} / \mathrm{ITO}$ ， (c) aptamer/UCNPs/Bi $2 \mathrm{~S}_{3} / \mathrm{ITO}$ incubated with AuNPs-cDNA, (d) aptamer/UCNPs/Bi $2 \mathrm{~S}_{3} / \mathrm{ITO}$ incubated with AuNPs-cDNA and $1 \mathrm{ng} \cdot \mathrm{mL}^{-1} \mathrm{AFB} 1$. 


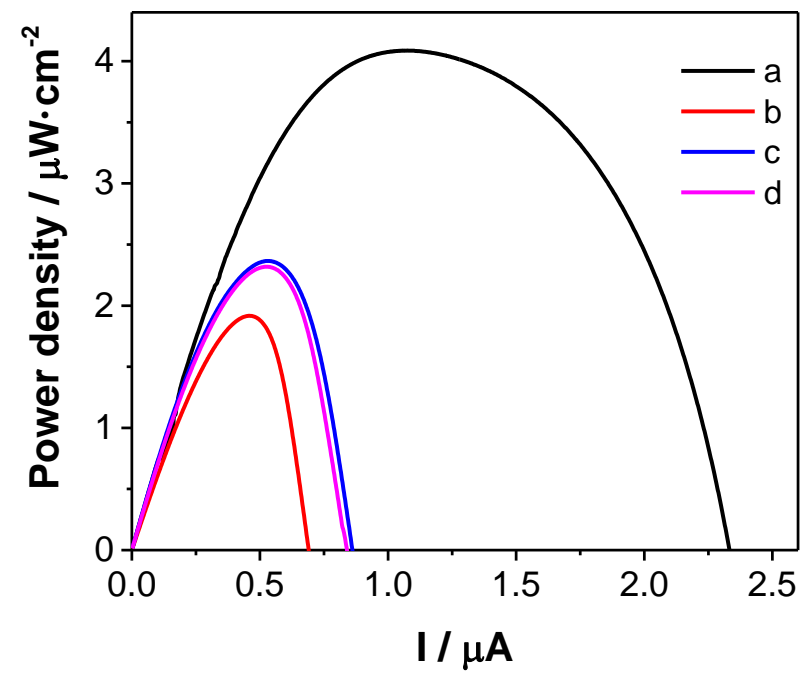

Figure S6. $P-I$ curves of PFCs constructed with Pt cathode and different photoanodes: (a) UCNPs/Bi2 $\mathrm{S}_{3} / \mathrm{ITO}$, (b) nonfunctional DNA sequence/UCNPs/Bi ${ }_{2} \mathrm{~S}_{3} / \mathrm{ITO}$, (c) nonfunctional DNA sequence/UCNPs/Bi ${ }_{2} \mathrm{~S}_{3} / \mathrm{ITO}$ incubated with AuNPs-cDNA, (d) nonfunctional DNA sequence/UCNPs/Bi2 $\mathrm{S}_{3} / \mathrm{ITO}$ incubated with AuNPs-cDNA and $1 \mathrm{ng} \cdot \mathrm{mL}^{-1} \mathrm{AFB} 1$. 

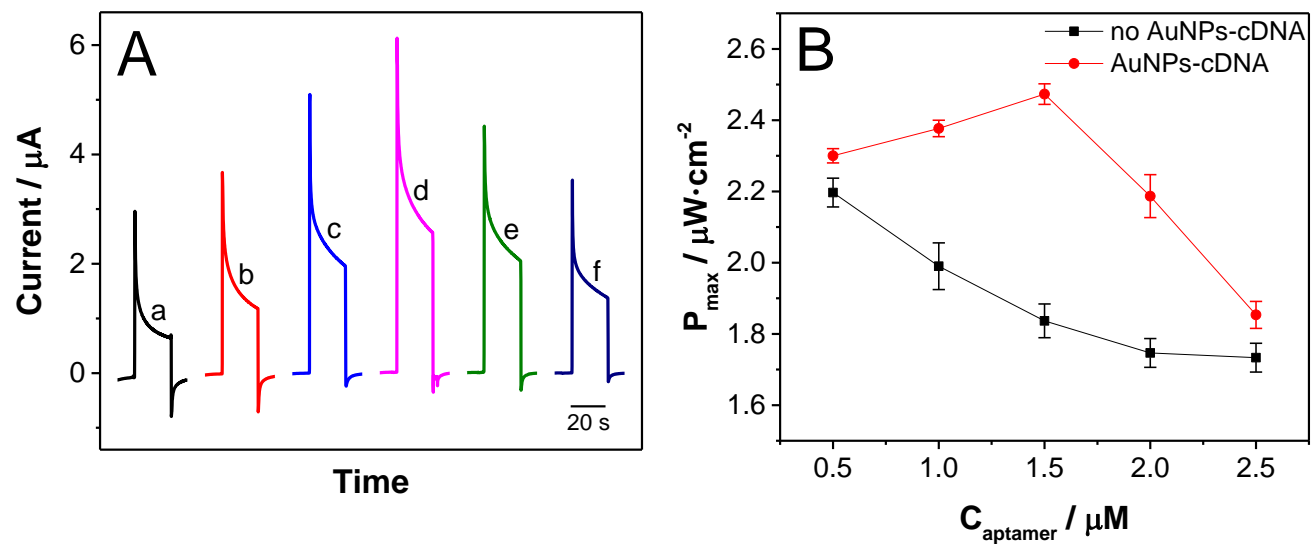

Figure S7. (A) Photocurrent responses of UCNPs $/ \mathrm{Bi}_{2} \mathrm{~S}_{3}$ containing different percentages of UCNPs: (a) 0 , (b) $5 \%$, (c) $10 \%$, (d) $15 \%$, (e) $20 \%$, (f) $30 \%$ recorded in $0.1 \mathrm{M} \mathrm{Na}_{2} \mathrm{SO}_{4}$ solution at a bias potential of $0 \mathrm{~V}$. (B) Influence of the aptamer concentration on the output of PFC (black: $15 \% \mathrm{UCNPs} / \mathrm{Bi}_{2} \mathrm{~S}_{3} / \mathrm{ITO}$ incubated with different concentrations of aptamer, red: $15 \% \mathrm{UCNPs} / \mathrm{Bi}_{2} \mathrm{~S}_{3} / \mathrm{ITO}$ incubated with different concentrations of aptamer and AuNPs-cDNA). The measurements of PFC were carried out in $0.1 \mathrm{M} \mathrm{Na}_{2} \mathrm{SO}_{4}$ solution under NIR light irradiation. 
Table S1. Comparison of analytical performance of different methods for AFB1 detection.

\begin{tabular}{cccc}
\hline Methods & Linear range & Detection limit & References \\
\hline Fluorescence & $0-3 \mathrm{ng} \cdot \mathrm{mL}^{-1}$ & $0.25 \mathrm{ng} \cdot \mathrm{mL}^{-1}$ & 5 \\
Fluorescence & $5-100 \mathrm{ng} \cdot \mathrm{mL}^{-1}$ & $1.6 \mathrm{ng} \cdot \mathrm{mL}^{-1}$ & 6 \\
$\begin{array}{c}\text { Electrochemical } \\
\text { method }\end{array}$ & $0.05-6 \mathrm{ng} \cdot \mathrm{mL}^{-1}$ & $0.05 \mathrm{ng} \cdot \mathrm{mL}^{-1}$ & 7 \\
$\begin{array}{c}\text { Electrochemical } \\
\text { method }\end{array}$ & $0.125-16 \mathrm{ng} \cdot \mathrm{mL}^{-1}$ & $0.12 \mathrm{ng} \cdot \mathrm{mL}^{-1}$ & 8 \\
$\begin{array}{c}\text { Photoelectrochemical } \\
\text { sensor }\end{array}$ & $0.01-20 \mathrm{ng} \cdot \mathrm{mL}^{-1}$ & $2.1 \mathrm{pg} \cdot \mathrm{mL}^{-1}$ & 9 \\
$\begin{array}{c}\text { Photoelectrochemical } \\
\text { sensor }\end{array}$ & $0.01-15 \mathrm{ng} \cdot \mathrm{mL}^{-1}$ & $2.8 \mathrm{pg} \cdot \mathrm{mL}^{-1}$ & 10 \\
Self-powered sensor & $0.01-100 \mathrm{ng} \cdot \mathrm{mL}^{-1}$ & $7.9 \mathrm{gg} \cdot \mathrm{mL}^{-1}$ & This work \\
\hline
\end{tabular}


Table S2. Detection of AFB1 in flour samples by ELISA and the proposed method ( $n=3)$.

\begin{tabular}{ccccc}
\hline Sample & $\begin{array}{c}\text { Added } \\
\left(\mathrm{ng} \cdot \mathrm{mL}^{-1}\right)\end{array}$ & $\begin{array}{c}\text { ELISA } \\
\left(\mathrm{ng} \cdot \mathrm{mL}^{-1}\right)\end{array}$ & $\begin{array}{c}\text { Proposed sensor } \\
\left(\mathrm{ng} \cdot \mathrm{mL}^{-1}\right)\end{array}$ & $\begin{array}{c}\text { Recovery } \\
(\%)\end{array}$ \\
\hline 1 & 0.1 & $0.11 \pm 0.016$ & $0.11 \pm 0.03$ & 110 \\
2 & 1 & $1.09 \pm 0.09$ & $0.97 \pm 0.06$ & 97 \\
3 & 10 & $10.25 \pm 0.15$ & $10.3 \pm 0.21$ & 103 \\
\hline
\end{tabular}




\section{References}

(1) Qiu, Z.; Shu, J.; Tang, D. NaYF4:Yb,Er upconversion nanotransducer with in situ fabrication of $\mathrm{Ag}_{2} \mathrm{~S}$ for near-infrared light responsive photoelectrochemical biosensor. Anal. Chem. 2018, 90, 12214-12220.

(2) Yin, H.; Wang, M.; Zhou, Y.; Zhang, X.; Sun, B.; Wang, G.; Ai, S. Photoelectrochemical biosensing platform for microRNA detection based on in situ producing electron donor from apoferritin-encapsulated ascorbic acid. Biosens. Bioelectron. 2014, 53, 175-181.

(3) Yuan, R.; Tang, D.; Chai, Y.; Zhong, X.; Liu, Y.; Dai, J. Ultrasensitive potentiometric immunosensor based on SA and OCA techniques for immobilization of HBsAb with colloidal Au and polyvinyl butyral as matrixes. Langmuir 2004, 20, 7240-7245.

(4) Gao, J.; Chen, Y. X.; Ji, W. H.; Gao, Z. H.; Zhang, J. D. Synthesis of a CdS-decorated Eu-MOF nanocomposite for the construction of a self-powered photoelectrochemical aptasensor. Analyst 2019, 144, 6617-6624.

(5) Jia, Y. M.; Wu, F.; Liu, P. L.; Zhou, G. H.; Yu, B.; Lou, X. D.; Xia, F. A label-free fluorescent aptasensor for the detection of aflatoxin B1 in food samples using AIEgens and graphene oxide. Talanta 2019, 198, 71-77.

(6) Chen, L.; Wen, F.; Li, M.; Guo, X.; Li, S.; Zheng, N.; Wang, J. A simple aptamer-based fluorescent assay for the detection of aflatoxin B1 in infant rice cereal. Food Chem. 2017, 215, 377382.

(7) Goud, K. Y.; Hayat, A.; Catanante, G.; Satyanarayana, M.; Gobi, K. V.; Marty, J. L. An electrochemical aptasensor based on functionalized graphene oxide assisted electrocatalytic signal amplification of methylene blue for aflatoxin B1 detection. Electrochim. Acta 2017, 244, 96-103.

(8) Goud, K. Y.; Catanante, G.; Hayat, A.; Satyanarayana, M.; Gobi, K. V.; Marty, J. L. Disposable and portable electrochemical aptasensor for label free detection of aflatoxin B1 in alcoholic beverages. Sens. Actuators B 2016, 235, 466-473.

(9) Lin, Y.; Zhou, Q.; Tang, D.; Niessner, R.; Knopp, D. Signal-on photoelectrochemical immunoassay for aflatoxin $\mathrm{B} 1$ based on enzymatic product-etching $\mathrm{MnO}_{2}$ nanosheets for dissociation of carbon dots. Anal. Chem. 2017, 89, 5637-5645.

(10) Su, L.; Tong, P.; Zhang, L.; Luo, Z.; Fu, C.; Tang, D.; Zhang, Y. Photoelectrochemical immunoassay of aflatoxin $\mathrm{B} 1$ in foodstuff based on amorphous $\mathrm{TiO}_{2}$ and $\mathrm{CsPbBr}_{3}$ perovskite nanocrystals. Analyst 2019, 144, 4880-4886. 